\title{
Interaction of 2-Hydroxyquinoxaline (2-HQ) on Soil Enzymes and Its Degradation: A Review
}

\author{
Venkata Subba Reddy Gangireddygari ${ }^{1}$, Rajasekhar Reddy Bontha ${ }^{2}$, and Ju-Yeon Yoon ${ }^{1 *}$ \\ ${ }^{1}$ Researcher, Horticultural and Herbal Crop Environment Division, National Institute of Horticultural and Herbal Science, RDA, Wanju 55365, Korea \\ ${ }^{2}$ Departmentof Microbiology, Sri Krishnadevaraya University, Anantapuramu-515003, A.P. India
}

\section{ABSTRACT}

The United Nations project the world population to reach 10 billion by the year 2057. To increase the food of the ever-increasing world population, agrochemicals are indispensable tools to the boon in agriculture production. These agrochemicals are a serious threat to the health of humans, plants, and animals. Agrochemicals are ultimately reached to the main reservoir/sink such as soil and contaminating the groundwater, disturb the soil health and in turn a serious threat to biogeochemical cycling and the entire biosphere. Among agrochemicals, quinalphosis one of the most repeatedly and widely used insecticides in the control of a wide range of pests that attack various crops. Quinalphos is shown to be primarily toxic in organisms by acetylcholinesterase enzyme action. Hydrolysis of quinalphos produces amajor metabolite 2-hydroxyquinoxaline (2-HQ), which has shown secondary toxicity in organisms. 2-HQ is reported to be mutagenic, carcinogenic, growth inhibition and induce oxidative stress in organisms. Quinoline is a heterocyclic compound and structural resemblance of 2-HQ with minor changes, but its degradation studies are enormous compared to the 2-HQ compound. Biotic factors in fate and behavior of 2-HQ in the environment are least studied. 2-HQ interactions with soil enzymes are vary from soil to soil. Based on the toxicity of $2-\mathrm{HQ}$ in our stockpile we need to isolate a handful of microorganisms to treat this persistent metabolite and also other metabolites/compounds. This brief review will be significant from the point of biological and environmental safety.

Keywords: decomposition, environmental safety, quinoxaline-2-ol, soil health, toxicity

\section{Introduction}

Man-made chemicals/naturally occurringchemicals are used to protect the health of plants, animals, and humans as well as to add economic or aesthetic value to plants and animals for their products. In agriculture, these chemicals are applied directly to crops almost at all stages of growth from planting to harvest storage or transport. Besides, the soil may be treated pre-planting and during plant growth for control of weeds and other pests which are abundant in agricultural soils. There are numerous chemicals for agricultural use in many waysof delivering to the target with concentration and formulation varying to suit the mode of application and the target. Pesticides are commonly applied and are used worldwide in agriculture to protect crops from pests and in public health to control diseases that are transmitted by vectors (Ramakrishnan et al., 2010).

Accidental spills/leaks occurring during transport and storage of industrial materials \& agricultural chemicals have polluted areas that were never intended as sites for waste disposal. Thus, soil and water bodies serve as ultimate sink/reservoir for all kinds of pesticides whether they are aimed intentionally/unintentionally applied. The interaction between pesticides and non-target organisms present

The authors are thankful to V. Narahari Kumar for his M.Phill thesis information.

Received: June 10, 2020, Revised: July 9, 2020, Accepted: July 21, 2020

First author: Venkata Subba Reddy Gangireddygari, visitsubbu@gmail.com, (D) https://orcid.org/0000-0002-4811-5849

*Corresponding author: Ju-Yeon Yoon, juyeon74@korea.kr, (1) https://orcid.org/0000-0003-1646-7310 
in soil/water bodies eventually leads to not only alteration in life-function of individual organisms but also disturbance in equilibrium among organisms thereby affecting the primary life support function of natural resources - soil and water bodies (Pimental and Levitan, 1986; Ramakrishnan et al., 2010). Impact of organic pollutants, in particular, agrochemicals on the capacity of aquatic/soil environments to support life has been the subject of extensive research worldwide as documented in earlier reviews (Ramakrishnan et al., 2010; Venkateswarlu, 1993). The influence of agrochemicals including organophosphates on non-target organisms is dependent on their concentrations prevailing in the environment after their entry.

Understanding of biotic and abiotic factors on the fate of organophosphorus pesticides in the environment is essential. Among organophosphates, quinalphos is one of the major insecticidesused in agriculture.

\section{Quinalphos and its metabolite - 2-HQ toxicity}

Quinalphos (O, O-diethyl O-quinoxaline-2-yl phosphorothioate), is one of the widely used organophosphorus broad-band based pesticide with both insecticidal and acaricidal properties. World Health Organization (WHO, 2004) assessed all agrochemicals used in the globe and ranked quinalphos is moderately hazardous. Because of its nature, it is either banned or restricted for usage in most of the nations. Quinalphos which is classified as a yellow label (highly toxic) pesticide in India, is widely used in large and repeated doses to control insect pests that attack many crops in agriculture and horticulture fields. Quinalphos shows high-level efficacy against a wide range of chewing, sucking, biting and leaf-mining pests, particularly in the orders of Lepidoptera, Homoptera, Coleoptera, Diptera, and Thysanoptera (Meyes, 1985). Becauseof its effective control of all pests over different crops, only $1 \%$ of the pesticide applied, hits the target pest, while the remaining $99 \%$ of the pesticide drifts into the environment contaminating soil, water and biota (Pimental and Levitan, 1986; Ramakrishnan et al., 2010) and disrupting the bio- geochemical cycling in nature.

Despite extensive usage of quinalphos in agriculture for control of pests over crops, inhibition of acetylcholinesterase (AChE) was reported in non-target organisms by quinalphos (Chebbi and David, 2009; Kopecka et al., 2004; Pan and Dutta, 1998; Silman and Sussman, 2005; Vig et al., 2006). Quinalphos adversely influence on blood and brain esterase activity in chickens (Vairamuthu and Thanikachalam, 2003), fish fertility efficiency in adult male rats (Sarkar et al., 2000) and also genotoxicity to silver barb (Sadiqul et al., 2017). A 3-year (2000-2002) evaluation report (Teixeira et al., 2004) of forensic pesticide and herbicide intoxications in Portugal indicated about 29\% of total cases due to quinalphos. Primary toxicity due to acetylcholinesterase inhibition is terminated by the hydrolysis of quinalphos and its metabolic products containing phosphorous detected in human serum and urine (Vasilić et al., 1992). There was the least attention focused on biotic factors than on abiotic factors in fate of quinalphos in natural resources (Babu et al., 1998; Banerjee and Dureja, 1999; Gangireddygari, Kalva, et al., 2017; Gonçalves et al., 2006; Gupta et al., 2011; Kaur and Sud, 2012; Subba Reddy, 2013; Talwar et al., 2014). Despite the complete disappearanceof quinalphos from soils within two weeks, its hydrolytic metabolite, 2-hydroxyquinoxaline was accumulated (Babu et al., 1998). As the secondary toxicity of the metabolite, 2-hydroxyquinoxaline (Fig. 1) equally poses a severe concern as the primary toxicity of the parent compound - quinalphos from the point of environmental safety. The presence of metabolites in soils may also exert their interactions with microflora and their microbial activities, thereby affecting soil fertility. The impact of metaboliteson microbial activities and biochemical transformations in soil received less attention in comparison to other parental in-

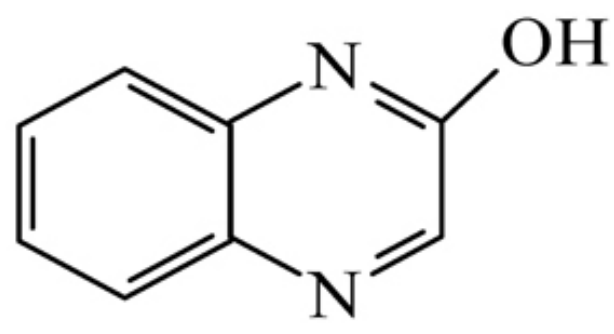

Fig. 1. 2-hydroxyquinoxaline structure. 
secticide metabolites. Knowledge of biotic factors involved in the fate of metabolite - 2-hydroxyquinoxaline is validated.

\section{The structural resemblance of 2-HQ - Quinoline and its degradation by microorganisms}

Quinoline $\left(\mathrm{C}_{9} \mathrm{H}_{7} \mathrm{~N}\right.$; Fig. 2) isan aromatic compound formed when benzene ring fuses with the pyridine ring, is an N-heterocyclic compound, occurs naturally in the environment and is used in numerous industrial processes. 2-Hydroxyquinoxaline (2-HQ; $\mathrm{C}_{8} \mathrm{H}_{6} \mathrm{~N}_{2} \mathrm{O}$ ) is an aromatic and bicyclic compound with the fusion of one benzene ring and one pyrazine ring and is getting accumulated in the environment-soil due to its slow degradation upon repeated applications of the parent compound-quinalphos (Babu et al., 1998). Quinoline is distinct from 2-HQ (2 nd position is occupied by a hydroxy group and additional nitrogen in the fourth position of the compound) also detected in the environment due to the production and application of quinoline-based drugs, quinoline-based dyes and petroleum products (Environmental Protection Agency, 2001; Fetzner, 1998; Padoley et al., 2008; Tuo et al., 2012). Good solubility, high mobility, and persistence of quinoline cause that it is detected in both aquatic and soil ecosystems (Blum et al., 2011; Hartnik et al., 2007; Reineke et al., 2007). Ecotoxicological effect of quinoline has been demonstrated toward bacteria, algae, daphnids, and soil invertebrates (Kobetičová et al., 2011; Sochová et al., 2011). It is also, genotoxic and mutagenic activities (Eisentraeger et al., 2008; Neuwoehner et al., 2009).

It is desirable to have microbial/bacterial cultures in our stockpile for mitigation of N-heterocyclic compounds asso-

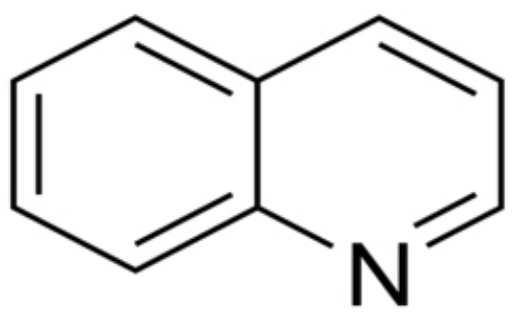

Fig. 2. Quinoline structure. ciated toxicity by enhancing the degradation of N-heterocyclic compounds in the environment. The number of bacterial cultures such as Bacillus sp. (Tuo et al., 2012), Pseudomonas sp. (Bai et al., 2009; Lin and Jianlong, 2010; Sun et al., 2009), Burkholderia pickettii (Jianlong et al., 2002) and Rhodococcus sp. (Zhu et al., 2008), Comamonas sp. (Cui et al., 2004); Brevundimonas sp. K4 (Wang et al., 2014); Pseudomonas citronellosis PY1 (Wang et al., 2020) and so on with the capacity to tolerate and degrade quinoline were reported.

In addition to reports of bacterial culture, there were few reports on the degradation of quinoline by fungal species. White rot fungi possess an ability to degrade pharmaceuticals, pesticides, and dyes (Cruz-Morató et al., 2013). Species of Aspergillus, Mucor, or Cochliobolus are widely used in the elimination of dangerous xenobiotics (Carvalho et al., 2011; Felczak et al., 2014; Krupiński et al., 2014). Also, fungi belonging to the genus of Cunninghamellaare well known for their ability to metabolize various pollutants. Cunninghamella species transform polyaromatic hydrocarbons like phenanthrene (Marco-Urrea et al., 2015; Pothuluri et al., 1996), tributyltin compounds (Bernat and Dlugoński, 2002), or drugs (Ahmad et al., 2014; Paludo et al., 2013). C. elegans IM1785/21Gp removes quinoline with high efficiency and transforms the pollutant into two novel hydroxylated derivatives, 2-hydroxyquinoline and 3-hydroxyquinoline (Felczak et al., 2016).

There were so many reports on the complete degradation and removal of quinoline by different microbial cultures, produced different types of metabolites (Bläse et al., 1996; Fetzner, 1998; Lin and Jianlong et al., 2010; O'Loughlin et al., 1996; Pereira et al., 1988; Schwarz et al., 1988; Sun et al., 2009) ultimately one common metabolite of molecular formula $\left(\mathrm{C}_{9} \mathrm{H}_{6} \mathrm{O}_{3}\right)$ having 8-hydroxy coumarin and then finally converted into atmospheric carbon dioxide and ammonium nitrogen (Wang et al., 2020). Whereas in the case of 2-hydroxyquinoxaline there is no much information on the complete degradation of the compound.

\section{Abiotic and biotic hydrolysis of quinalphos}

Hydrolysis of the ester bond to the aromatic moiety in 
quinalphos leads to the formation of 2-hydroxyquinoxaline which has been identified as the main metabolite in soil, in water, and on crops (Awasti and Ahuja, 1989; Babu et al., 1998; Menon and Gopal, 2003). The 2-Hydroxyquinoxaline metabolite was formed through $\mathrm{pH}$-independent hydrolysis probably mediated by microbes, proceeding with a further breakdown (Menon and Gopal, 2003). In the same study hydrolysis of quinalphos followed two pathways depending on the nature of the cation. 2-Hydroxyquinoxaline (nucleophilic attack at the aliphatic $\mathrm{C}$ ) was formed in the presence of $\mathrm{Na}, \mathrm{K}$, and Ca-clays. Esbata et al. studied the degradation of quinalphos under controlled conditions in the basic aqueous solutions in the presence and absence of $\mathrm{MnO}_{2}$ and $\mathrm{TiO}_{2}$ with $\mathrm{pH}$ range 11.8-13.6 at five different temperatures $25,30,35,40$, and $45^{\circ} \mathrm{C}$ by following spectrophotometrically the appearance of the product 2-hydroxyquinoxaline (Esbata et al., 2017; Fig. 3).

Dureja et al. (1988) also studied the photodegradation of quinalphos in distilled, tap, and rainwater and in aqueous acetone by exposure to natural sunlight formed 2-hydroxyquinoxaline. In another study about the photolytic degradation of quinalphos in natural waters and on soil matrices under simulated solar irradiation conditions reported 2-hydroxyquinoxaline is the main metabolite (Gonçalves et al., 2006). Decay profile and metabolism of quinalphos were studied in soil, water, and plants reported 2-hydroxyquinoxaline is the main metabolite and more toxic thanthe parent compound and persist for a long time (Gupta et al., 2011). A combination of $\mathrm{TiO} 2$ and UV light together caused more rapid degradation of quinalphos and formed to quinalphos-oxon, hydroxylated quinalphos and dealkylation of phosphate moiety (Kaur and Sud, 2012). An isolated bacterial strain - Ochrobactrum sp. strain HZM degraded quinalphos and produced 2-hydroxyquinoxaline as the main metabolite (Talwar et al., 2014). Gangireddygari, Kanderi, et al. (2017) also reported that quinalphos was degraded by Bacillus subtilis and formed 2-hydroxyquinoxaline as the main metabolite (Fig. 3).

\section{Effects of 2-HQ on organisms}

This study had been initiated by observations in quinalphos exposed mammals and birds, which exhibited an obvious impairment of immunological parameters along with a decrease in melatonin (Haldar, unpublished data). Since melatonin easily scavenges free radicals and several other oxidants, it can be consumed by reactive intermediates and a decline as observed may indicate oxidative stress (Hardeland et al., 1999; Hardeland and Coto-Montes, 2000; Hardeland et al., 2000). Concerning melatonin immunomodulatory properties (Guerrero and Reiter, 2002; Haldar, 2002; Hardeland et al., 2005), a drop in melatonin level would be also under immunological dysfunctions. Since the organophosphate quinalphos does not dispose of reactive groups capable of inducing oxidative stress directly, we assumed secondary toxicity induced by the metabolite 2-HQ an electron-rich molecule containing two nitrogen atoms and carrying a hydroxyl group, which should easily undergo redox reactions, perhaps via an intermediate quinoxaline-2-oxyl radical. In vitro, 2-HQ can destroy vitamin $\mathrm{C}$ and $\mathrm{E}$, oxidizing various biogenic amines such as serotonin, melatonin, the melatonin metabolite - N1-acetyl-5-methoxykynuramine (AMK), dopamine, norepinephrine, epinephrine, and unsubstituted and substituted anthranilic acid derivatives when exposed to light (Behrends et al., 2004; Behrends et al., 2007).

2-HQ toxicity was studied in several phylogenetically unrelated organisms such as rotifer - Philodina acuticornis, dinoflagellate - Lingulodinium polyedrum and ciliate Paramecium bursaria and proved it induces oxidative

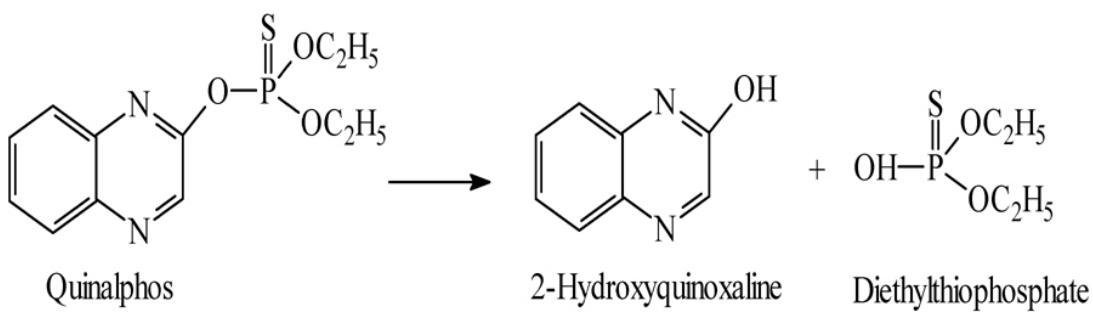

Fig. 3. Quinalphos hydrolysis by abiotic and biotic factors. 
stress and mutations. Philodinais an established model organism for testing oxidotoxicity, antioxidant effects and gerontoprotection (Meadow and Burrows, 1971; Poeggler and Hardeland, 2001; Poeggeler et al., 2005). 2-HQ treated Philodina acuticornis body size is dropped and the life span is also reduced. In the dinoflagellate, 2-HQ strongly induce the oxidative stress by strongly increasing protein carbonyl, a major oxidative protein modification. In an entirely different test organism, the ciliate Paramecium bursaria, which is also sensitive to oxidotoxins, 2-HQ caused an inhibition of cell proliferation and at the higher concentration decreased cell number.

In an Ames test of mutagenicity using the particularly suitable and sensitive, histidine-auxotroph strain Salmonella typhimurium TA-102, 2-HQ proved to be genotoxic for both light and dark exposed bacteria (Riediger et al., 2007).

\section{Influence of 2-HQ on the bacterial growth rate}

To find out the growth kinetics of 2-HQ on a bacterium, minimal salts medium (MSM) fortified with 2-HQ at a concentration of $50 \mathrm{ppm} \mathrm{mL} \mathrm{m}^{-1}$ in $250 \mathrm{~mL}$ of Erlenmeyer flasks with the two bacterial species - Bacillus sp. and Ochrobactrum sp. HQ1 isolated from soil. (Subba Reddy et al., 2014; Subba Reddy et al., 2016). The flasks were incubated in an orbital shaker at $175 \mathrm{rpm}$ at $37^{\circ} \mathrm{C}$ for 24 hr. Five-milliliter aliquots from growing culture broth were withdrawn aseptically at $6 \mathrm{hr}$ intervals and growth monitored at $600 \mathrm{~nm}$ in a UV-Visible spectrophotometer (Chemito UV-2600). The total number of viable bacterial colony-forming units was determined by the serial dilution method on nutrient agar medium. The specific growth rate of two bacterial isolates Bacillus sp. and Ochrobactrumsp. HQ1 was calculated in the logarithmic phase as per the equation - $\mathrm{K}=\log \mathrm{N}_{\mathrm{t}}-\log \mathrm{N}_{0} / \log 2 \mathrm{x}$ t.

The viable cell count in the growing culture of bacteria on 2-HQ was measured at regular intervals of $6 \mathrm{hrs}$. At the beginning ( 0 times) immediately after inoculation the viable cell count of is $28 \times 10^{9}$ and $84 \times 10^{9} \mathrm{CFU} / \mathrm{mL}$ was recorded in respect of Bacillus sp. and Ochrobacturm sp.
HQ1. After incubation for $6 \mathrm{hr}$, the initial total viable cell count rose to $50 \times 10^{9}$ and $158 \times 10^{9} \mathrm{CFU} / \mathrm{mL}$ in the culture of Bacillus sp. and Ochrobacturmsp. HQ1. During this $\log$ phase both the bacterial species, growth rate and generation time calculated. Doubling time of Bacillus sp. and Ochrobacturm sp. HQ1 at the log/exponential phase is 0.79 $\mathrm{h}$ or 47.4 and $0.71 \mathrm{~h}$ and $42.6 \mathrm{~min} /$ generation, respectively (Subba Reddy et al., 2014; Subba Reddy et al., 2016).

To date, there is no detailed research report on the effect of 2-hydroxyquinoxaline on species-specific soil microorganism comparing with other bacterial and fungal species with other agrochemicals available in the market.

\section{Effect of 2-HQ on soil enzyme activities}

Soil is a living, dynamic and nonrenewable source. The total sustainability of soilnatural functions depends on soil quality and health and the delicate balance among different microorganisms that determine the recycling of nitrogen, carbon and other valuable plant nutrients. The entry of agro-chemicals including pesticides into the soil due to agricultural practices can influence equilibrium among microflora in the soil, thereby affecting soil fertility. Soil natural functions under the influence of agrochemicals continuously need to be monitored using key indicators of biological and biochemical parameters. Because of rapid formation of 2-hydroxyquinoxaline from a widely used organophosphorus insecticide, quinalphos in soil, the impact of 2-hydroxyquinoxaline at two concentrations 2 and $10 \mathrm{ppm}$ on nitrogen mineralization and six important soil enzyme (Cellulase and amylase, protease, urease, phosphatase, and dehydrogenase) activities representative of carbon, nitrogen, and phosphorus cycles were assessed in two soils black soil [black soil properties -sand (\%)-74, silt (\%)- 16, clay (\%)-10, texture-loamy sand, alkaline nature, $\mathrm{pH}-8.1$; Electrical conductivity $(\mathrm{ds} / \mathrm{m})^{2}-0.048$, organic matter $(\%)$ - 1.34, water holding capacity - 40, available nutrients (Kg/ha) - N-200. $\mathrm{P}_{2} \mathrm{O}_{5}-15.4, \mathrm{~K}_{2} \mathrm{O}_{5}-183$ ]; and red soil [red soil properties - sand (\%)-70 silt (\%)- 23 clay (\%)-07 sandy loam and, acidic, pH-6.4, Electrical conductivity $(\mathrm{ds} / \mathrm{m})^{2}-0.230$, organic matter $(\%)-0.536$, water holding capacity - 23, available nutrients $(\mathrm{Kg} / \mathrm{ha})-\mathrm{N}-226 . \mathrm{P}_{2} \mathrm{O}_{5-}$ 
56.4, $\mathrm{K}_{2} \mathrm{O}_{5}-149$ ] collected from groundnut field for a laboratory study (Narahari Kumar, 2005).

\section{Effect of 2-HQ on nitrogen mineralization}

Mineralization of exogenously added organic peptone in soils treated with 2- hydroxyquinoxaline was studied aerobic conditions. The total ammonifying activity of soils is the sum of different forms of inorganic nitrogen $\left(\mathrm{NH}_{4}{ }^{+}\right.$$\mathrm{N}+\mathrm{NO}_{2}^{-}-\mathrm{N}+\mathrm{NO}_{3}^{-}-\mathrm{N}$ ). The application of 2-hydroxyquinoline was not toxic to ammonification in red soil even at a higher concentration of $10 \mathrm{ppm}$. But, ammonifying activity was depressed in 2-hydroxyquinoxaline amended black soil at both concentrations on the 10thday of incubation in comparison to control. This inhibition was alleviated in the black soil at a later stage of incubation. Quantification of nitrite and nitrate, formed due to oxidation of ammonium in soil, represents total nitrifying activity. Like ammonification, nitrification was not influenced by the presence of 2-hydroxyquinoxaline at both concentrations in the red soil. But, 2-hydroxyquinoxaline was stimulatory to nitrification in the black soil (Narahari Kumar, 2005)

\section{Effect of 2-HQ on cellulase and amylase activity}

2-Hdroxyquinoxaline was toxic to cellulase activity in the black soil at both concentrations on earlier interval 10th day of incubation. About 19 and 37\% decreases in cellulase activity occurred in 2-hydroxyquinoxaline-amended black soil at 2 and $10 \mathrm{ppm}$, respectively on the 10th day of incubation. Recovery of cellulase activity from this incubation was made at the later stage of incubation. 2-hydroxyquinoxaline wasless toxic to cellulase activity in the red soil. 2-Hydroxyquinoxaline was innocuous to amylase activity in both soils even at a higher concentration of 10 ppm (Narahari Kumar, 2005).

\section{Effect of 2-HQ on protease activity}

Protease activity was tested in black and red soils of groundnut fields with the concentrations of 2 and $10 \mathrm{ppm}$, 2-Hydroxyquinoxaline was not toxic to protease activity in red soil at both concentrations 2 and $10 \mathrm{ppm}$. But the same metabolite enhanced protease activity in the black soil on the 10th day of incubations at both concentrations (Narahari Kumar, 2005).

\section{Effect of 2-HQ on urease activity}

To determine the urease activity in both black and red soil, soil samples were fortified with 2-hydroxyquinoxaline at concentrations of 2 and $10 \mathrm{ppm}$. Application of 2-hydroxyquinoxaline even at higher concentration 10 ppm did not affect urease activity in both soils (Narahari Kumar, 2005).

\section{Effect of 2-HQ on phosphatase activity}

Phosphatase activity was measured in black and red soils of groundnut fields with the concentrations of 2 and 10 $\mathrm{ppm}$. The occurrence of the rate of hydrolysis of $p$-nitrophenyl phosphate to the same extent in both soils with/without 2-hydroxyquinoxaline indicating the innocuous nature of the metabolite. Nearly sixty microorganisms of $p$-nitrophenol per $\mathrm{g}$ of soil were released from $p$-nitrophenyl phosphate in control and 2-hydroxyquinoxaline-amended black soil on the 10th day of incubation (Narahari Kumar, 2005).

\section{Effect of 2-HQ on dehydrogenase activity}

Narahari Kumar (2005), demonstrated the dehydrogenase activity in red and black soils. Soil samples were spiked with 2-hydroxyquinoxaline at concentrations of 2 and $10 \mathrm{ppm}$ and enzyme activity were measured. 2-Hydroxyquinoxaline reduced dehydrogenase activity in the black soil at higher concentrations. The same metabolite at a lower concentration, $2 \mathrm{ppm}$ was innocuous to dehydrogenase activity in the black soil. Depression in dehydrogenase activity in the red soil amended with 2-hydroxyquinoxaline even at low concentration, $2 \mathrm{ppm}$ was recorded (Narahari Kumar, 2005).

\section{2-HQ degradation in minimal salts medium}

There was the least attention on the degradation of 2-HQ, comparison to degradation studies of other organophosphates 
- chlorpyrifos, methyl parathion, and its metabolite- $p$-nitrophenol and other metabolites in the environment. 2-Hydroxyquinoxaline degrading bacterial species were isolated from soil samples by selective enrichment method (Subba Reddy et al., 2014: Subba Reddy et al., 2016). This is the first research report on the isolation, identification, and characterization of microorganisms capable to degrade 2-HQ as the sole source of carbon and energy in minimal salts medium. A recent report evidenced that, the 2-HQ degradation was recorded by a novel aerobic gram-positive bacterium species - Bacillussp. and aerobic gram-negative bacterium - Ochrobactrum sp. HQ1 was identified (Subba Reddy et al., 2014: Subba Reddy et al., 2016). The authors were tested degradation efficiency of bacterial cultures by the addition of additional sources $(0.01 \%)$ of different types of carbon (glucose and sodium acetate) and nitrogen sources (ammonium chloride, ammonium sulfate, urea and yeast extract). Among the additional carbon and nitrogen sources, carbon sources did not influence the degradation rate of 2-HQ by both species, but nitrogen sources - yeast extract marginally enhanced the rate of degradation of 2-HQ by both bacterial species - Bacillus sp. and
Ochrobactrumsp. HQ1 (Subba Reddy et al., 2014: Subba Reddy et al., 2016). In another way effect of biotic factors tested, such as the size of inoculum (0.5 OD, $0.75 \mathrm{OD}$, and 1.0 OD) and co-culturingstudies on the degradation of 2-HQ, but 1.0 OD of inoculum significantly improved the degradation rate of 2-hydroxyquinoxaline compared to lower OD inoculum size. Co-culturing conditions of 2-HQ degradation were evaluated with two bacterial species, results unmasked that, there was no significant improvement in the rate of degradation of 2-HQ in a mixed culture of Ochrobactrum sp. HQ1 and Bacillus bacterium HQ2 when compared with the individual bacterial cultures degradation (Subba Reddy, 2013). The optimal conditions for 2-HQ degradation by both potential bacterial cultures Bacillus sp. and Ochrobactrum sp. HQ1, pH of 7-8, the temperature of $37-45^{\circ} \mathrm{C}$ and 2-HQ concentration of 500 ppm (Subba Reddy et al., 2014; Subba Reddy et al., 2016).

GC-MS analysis report evidenced that, the tentative 2-HQ degradation pathway has been elucidated with the bacterial species of Bacillus sp. (Subba Reddy et al., 2014; Fig. 4) and Ochrobactrum sp. HQ1 (Subba Reddy et al., 2016). In that degradation pathways initially, two mole-
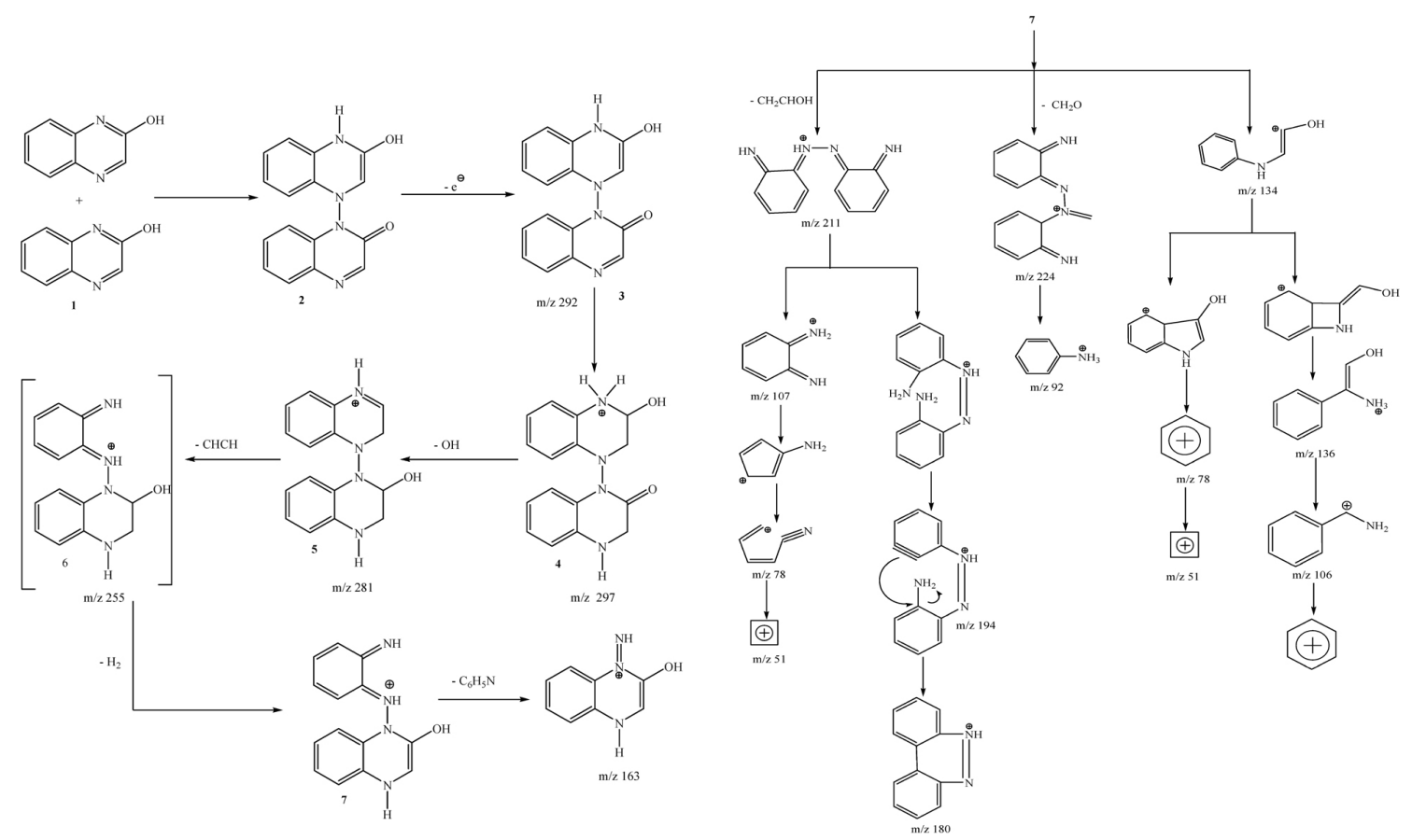

Fig. 4. Tentative degradation pathway of 2-HQ by Bacillus sp. Reprinted from "Biodegradation of 2-hydroxyquinoxaline (2-HQ) by Bacillus sp.", by G.V. Subba Reddy, B.R. Reddy, and M.G. Tlou, 2014, Journal of Hazardous Materials, 278, pp. 100-107. 
cules of 2-hydroxyquinoxaline molecules joined together to form a dimer with a molecular mass of 292 and proceed with the degradation process. Among the various metabolites $\mathrm{m} / \mathrm{z}$ values of the GC-MS chromatogram, one of the metabolites with $\mathrm{m} / \mathrm{z}$ value of 207 would be expected with the opening of pyrazine ring in dimer metabolite (Subba Reddy et al., 2014; Subba Reddy et al., 2016). Two types of bacterial species show same pattern on degradation of 2-HQ but variation in their fragmentation and intermediate molecules. The pyrazine nucleus possesses remarkable pharmaceutical importance and biological activities, and some of their derivatives occur as natural products.

\section{Conclusion}

The primary toxicity of quinalphos is due to acetylcholinesterase action, on the hydrolysis of quinalphos, which gives 2-HQ, which shown to be mutagenic, carcinogenic, genotoxic in organisms and intoxication of humans too. Secondary toxicity of 2-HQ was assessed in a limited manner. So, it needs to be further studied in-depth on how 2-HQ interacts with other soil biota and vertebrates. In red soil, 2-HQ was innocuous to ammonification, nitrification, cellulase, amylase, protease, urease, and phosphatase activity at both concentrations of 2 and $10 \mathrm{ppm}$ but it was only toxic to dehydrogenase activity at 2 and $10 \mathrm{ppm}$. But whereas in black soil, 2-HQ was innocuous to nitrification, amylase, protease, urease, and phosphatase but depressed and toxic effect on ammonification and cellulase activity even at low and high concentrations of 2 and10 ppm respectively. All these enzymes are involved in the recycling of carbon, nitrogen and phosphorus in the environment. During the degradation of 2-HQ by soil microbes, different types of metabolite are going to be formed. These metabolites are heterocyclic organic moieties. Due to the innocuousactivity of soil enzymes on 2-HQ, its metabolites may be mineralization by soil enzymes and play a significant role in the recycling of carbon, nitrogen and phosphorus in the environment.

\section{References}

Ahmad, M.S., S. Zafar, M. Bibi, S. Bano, A. Wahab, A. Rahman, and M. Iqbal Choudhary. 2014. Biotransformation of androgenic steroid mesterolone with Cunninghamella blakesleeana and Macrophomina phaseolina. Steroids 82:53-59. https://doi.org/10.1016/j.steroids.2014.01.001

Awasti, M.D. and A.K. Ahuja. 1989. Dissipation pattern of monocrotophos, quinalphos and phosphamidon residues on acid lime fruits and their movement behavior to fruit juice. Indian J. Hortic. 46:480-484.

Babu, G.V.A.K., B.R. Reddy, G. Narasimha, and N. Sethunathan. 1998. Persistence of quinalphos and occurrence of its primary metabolite in soils. Bull. Environ. Contam. Toxicol. 60:724-731. https://doi.org/1 $0.1007 / \mathrm{s} 001289900686$

Bai, Y., Q. Sun, C. Zhao, D. Wen, and X. Tang. 2009. Simultaneous biodegradation of pyridine and quinoline by two mixed bacterial strains. Appl. Microbiol. Biotechnol. 82(5):963-973. https://doi.org/10.1007/s00253-009-1892-0

Banerjee, K. and P. Dureja. 1999. Phototransformation of quinalphos on clay surfaces. Toxicol. Environ. Chem. 68(3-4):475-480. https://doi.org/10.1080/027722499093 58679

Behrends, A., R. Hardeland, H. Ness, S. Grube, B. Poeggeler, and C. Haldar. 2004. Photocatalytic actions of the pesticide metabolite 2-hydroxyquinoxaline: Destruction of antioxidant vitamins and biogenic amines - implications of organic redox cycling. Redox Rep. 9(5):279-288. https://doi.org/10.1179/135100004225006759

Behrends, A., S. Riediger, S. Grube, B. Poeggeler, C. Haldar, and R. Hardeland. 2007. Photocatalytic mechanisms of indoleamine destruction by the quinalphos metabolite 2-hydroxyquinoxaline: a study on melatonin and its precursors serotonin and N-acetyl serotonin. J. Environ. Sci. Health B. 42(6):599-606. https://doi.org/10.1080/03 601230701465437

Bernat, P. and J. Dlugoński. 2002. Degradation of tributyltin by the filamentous fungus Cunninghamella elegans, with involvement of cytochrome P-450. Biotechnol. Lett. 24: 1971-1974. https://doi.org/10.1023/A:1021177716010

Bläse, M., C. Bruntner, B. Tshisuaka, S. Fetzner, and F. Lingens. 1996. Cloning, expression, and sequence analysis of the three genes encoding quinoline 2-oxidor- 
eductase, a molybdenum-containing hydroxylase from Pseudomonas putida 86. J. Biol. Chem. 271(38): 23068-23079. https://doi.org/10.1074/jbc.271.38.23068

Blum, P., A. Sagner, A. Tiehm, P. Martus, T. Wendel, and P. Grathwohl. 2011. Importance of heterocyclic aromatic compounds in monitored natural attenuation for coal tar contaminated aquifers: A review. J. Contam. Hydrol. 126(3-4):181-194. https://doi.org/10.1016/j.jcon hyd.2011.08.004

Carvalho, M.B., S. Tavares, J. Medeiros, O. Núñez, H. Gallart-Ayala, M.C. Leitão, M.T. Galceran, A. Hursthouse, and C.S. Pereira. 2011. Degradation pathway of pentachlorophenol by Mucor plumbeus involves phase II conjugation and oxidation-reduction reactions. J. Hazard. Mater. 198:133-142. https://doi.org/10.1016/j.jh azmat.2011.10.021

Chebbi, S.G. and M. David. 2009. Neurobehavioral responses of the freshwater Teleost, Cyprinus carpio L. under quinalphos intoxication. Biotechnol. Anim. Husb. 25(3-4):241-249. https://doi.org/10.2298/BAH0904241C

Cruz-Morató, C., L. Ferrando-Climent, S. Rodriguez-Mozaz, D. Barceló, E. Marco-Urrea, T. Vicent, and M. Sarrà. 2013. Degradation of pharmaceuticals in non-sterile urban wastewater by Trametes versicolorin a fluidized bed bioreactor. Water Res. 47(14):5200-5210. https://doi.org/10.1016/j.watres.2013.06.007

Cui, M.C., F.Z. Chen, J.M. Fu, G.Y. Sheng, and G.P. Sun. 2004. Microbial metabolism of quinoline by Comamonas sp. World J. Microbiol. Biotechnol. 20:539-543. https:// doi.org/10.1023/B:WIBI.0000043149.61562.3f

Dureja, P., S. Wallia, and S.K. Mukerjee. 1988. Multiphase photodegradation of quinalphos. Pestic. Sci. 22(4):287-295. https://doi.org/10.1002/ps.2780220402

Eisentraeger, A., C. Brinkmann, H. Hollert, A. Sagner, A. Tiehm, and J. Neuwoehner. 2008. Heterocyclic compounds: toxic effects using algae, daphnids, and the Salmonella/microsome test taking methodical quantitative aspects into account. Environ. Toxicol. Chem. 27(7):1590-1596. https://doi.org/10.1897/07-201

Environmental Protection Agency. 2001. Toxicological review of quinoline (Report No. CAS No.91-22-5). Washington, DC: U.S. Environmental protection agency. Retrieved from https://cfpub.epa.gov/ncea/iris/iris_docu ments/documents/toxreviews/1004tr.pdf
Esbata, A., E. Buncel, G.W. vanLoon. 2017. $\mathrm{MnO}_{2}$ and $\mathrm{TiO}_{2}$ catalyzed the hydrolysis of quinalphos. Alq. J. Med. App. Sci.1(2):20-28. Retrieved from https://alqala m.utripoli.edu.ly/science/

Felczak, A., P. Bernat, and J. Długoński. 2014. Biodegradation of octyltin compounds by Cochliobolus lunatus and influence of xenobiotics on fungal fatty acid composition. Process Biochem. 49(2):295-300. https://doi.org/10.101 6/j.procbio.2013.12.001

Felczak, A., P. Bernat, S. Różalska, and K. Lisowska. 2016. Quinoline biodegradation by filamentous fungus Cunninghamella elegans and adaptive modifications of the fungal membrane composition. Environ. Sci. Pollut. Res. 23:8872-8880. https://doi.org/10.1007/s11356-0166116-4

Fetzner, S. 1998. Bacterial degradation of pyridine, indole, quinoline, and their derivatives under different redox conditions. Appl. Microbiol. Biotechnol. 49:237-250. https://doi.org/10.1007/s002530051164

Gangireddygari, V.S.R., P.K. Kalva, K. Ntushelo, M. Bangeppagari, A.D. Tchatchou, and R.R. Bontha. 2017. Influence of environmental factors on biodegradation of quinalphos by Bacillus thuringiensis. Environ. Sci. Eur. 29:11. https://doi.org/10.1186/s12302-017-0109-x

Gangireddygari, V.S.R., D. Kanderi, R. Golla, M. Bangeppagari, V.A.K.B. Gundi, K. Ntushelo, and R.R. Bontha. 2017. Biodegradation of quinalphos by a soil bacterium Bacillus subtilis. Pak. J. Biol. Sci. 20(8):410-422. https://doi.org/10.3923/pjbs.2017.410.422

Gonçalves, C., A. Dimou, V. Sakkas, M.F. Alpendurada, and T.A. Albanis. 2006. Photolytic degradation of quinalphos in natural waters and on soil matrices under simulated solar irradiation. Chemosphere 64(8):1375-1382. https://doi.org/10.1016/j.chemosphere.2005.12.020

Guerrero, J.M. and R.J. Reiter. 2002. Melatonin-immune system relationships. Curr. Top. Med. Chem. 2(2):167-179. https://doi.org/10.2174/1568026023394335

Gupta, B., M. Rani, R. Kumar, and P. Dureja. 2011. Decay profile and metabolic pathways of quinalphos in water, soil and plants. Chemosphere 85(5):710-716. https://doi. org/10.1016/j.chemosphere.2011.05.059

Haldar, C. 2002. Apoptosis, cancer, immunity and melatonin. In: C. Haldar, M. Singaravel, and S.K. Maitra (Eds.), Treatise on pineal gland and melatonin (pp. 535-542). 
Enfield, NH: Science Publishers.

Hardeland, R., S. Burkhardt, I. Antolín, B. Fuhrberg, and A. Coto-Montes. 1999. Melatonin and 5-methoxytryptamine in the bioluminescent dinoflagellate Gonyaulax polyedra: Restoration of the circadian glow peak after suppression of indoleamine biosynthesis or oxidative stress. Adv. Exp. Med. Biol. 460:387-390.

Hardeland, R. and A.Coto-Montes. 2000. Chronobiology of oxidative stress and antioxidative defense mechanisms. In: S.G. pandalai (Ed.), Recent research developments in comparative biochemistry and physiology, Vol. 1 (pp. 123-137). Trivandrum, India: Transworld Research Network.

Hardeland, R., A. Coto-Montes, S.Burkhardt, and B.K. Zsizsik. 2000. Circadian rhythms and oxidative stress in non-vertebrate organisms. In: T.V. Driessche, J.L. Guisset, and G.M. Petiau-de Vries (Eds.), The redox state and circadian rhythms (pp. 121-140). Dordrecht: Springer.

Hardeland, R., S.R. Pandi-Perumal, and D.P. Cardinali. 2005. Molecules in focus: Melatonin. Int. J. Biochem. Cell Biol. 38(3):313-316. https://doi.org/10.1016/j.bioce 1.2005.08.020

Hartnik, T., H.R. Norli, T. Eggen, and G.D. Breedveld. 2007. Bioassay-directed identification of toxic organic compounds in creosote-contaminated groundwater. Chemosphere 66(3):435-443. https://doi.org/10.1016/j.c hemosphere.2006.06.031

Jianlong, W., Q. Xiangchun, H. Liping, Q. Yi, and W. Hegemann. 2002. Kinetics of co-metabolism of quinoline and glucose by Burkholderia pickettii. Process Biochem. 37(8):831-836. https://doi.org/10.1016/S0032-9592(01) 00285-0

Kaur, P. and D. Sud. 2012. Photolytic degradation of quinalphos in aqueous $\mathrm{TiO}_{2}$ suspension: Reaction pathway and identification of intermediates by GC/MS. J. Mol. Catal. A Chem. 365:32-38. https://doi.org/10.1016/j.mol cata.2012.08.005

Kobetičová, K., Z. Šimek, J. Brezovský, and J. Hofman. 2011. Toxic effects of nine polycyclic aromatic compounds on Enchytraeus crypticus in artificial soil in relation to their properties. Ecotoxicol. Environ. Saf. 74(6): 1727-1737. https://doi.org/10.1016/j.ecoenv.2011.04.013

Kopecka, J., A. Rybakowas, J. Barsiene, and J. Pempkowiak. 2004. AChE levels in mussels and fish collected off
Lithuania and Poland (Southern Baltic). Oceanologia 46(3):405-418.

Krupiński, M., T. Janicki, B. Pałecz, and J. Długoński. 2014. Biodegradation and utilization of 4-n-nonylphenol by Aspergillus versicolor as a sole carbon and energy source. J. Hazard. Mater. 280:678-684. https://doi.org/1 0.1016/j.jhazmat.2014.08.060

Lin, Q. and W. Jianlong. 2010. Biodegradation characteristics of quinoline by Pseudomonas putida. Bioresour. Technol. 101(19):7683-7686. https://doi.org/10.1016/j.b iortech.2010.05.026

Marco-Urrea, E., I. García-Romera, and E. Aranda. 2015. Potential of nonligninolytic fungi in bioremediation of chlorinated and polycyclic aromatic hydrocarbons. $\mathrm{N}$. Biotechnol. 32(6):620-628. https://doi.org/10.1016/j.nbt. 2015.01.005

Meadow, N.D. and C.H. Barrows Jr. 1971. Studies on aging in a bdelloid rotifer. II. The effects of various environmental conditionsand maternal age on longevity and fecundity. J. Gerontol. 26(3):302-309. https://doi.or g/10.1093/geronj/26.3.302

Menon, P. and M. Gopal. 2003. Dissipation of ${ }^{14} \mathrm{C}$-Carbaryl and quinalphos in soil under a groundnut crop (Arachis hypogaea L.) in semi-arid India. Chemosphere 53(8): 1023-1031. https://doi.org/10.1016/S0045-6535(03)00671-4

Meyes, P. 1985. United States Patent (Patent No: 4510137, Dated: Apr. 9, 1985). Retrieved from https://patentimag es.storage.googleapis.com/34/a4/a7/7d9c6e77011381/U S4510137.pdf

Narahari Kumar, V. 2005. Effect of 2-hydroxyquinoxaline on soil enzyme activities. Master's thesis, Sri Krishnadevaraya University, Anantapuramu, A.P. India.

Neuwoehner, J., A.K. Reineke, J. Hollender, and A. Eisentraeger. 2009. Ecotoxicity of quinoline and hydroxylated derivatives and their occurrence in groundwater of a tar-contaminated field site. Ecotoxicol. Environ. Saf. 72(3):819-827. https://doi.org/10.1016/j.ec oenv.2008.04.012

O'Loughlin, E.J., S.R. Kehrmeyer, and G.K. Sims. 1996. Isolation, characterization, and substrate utilization of a quinoline-degrading bacterium. Int. Biodeterior. Biodegradation 38(2):107-118. https://doi.org/10.1016/ S0964-8305(96)00032-7

Padoley, K.V., S.N. Mudliar, and R.A. Pandey. 2008. 
Heterocyclic nitrogenous pollutants in the environment and their treatment options: An overview. Bioresour. Technol. 99(10):4029-4043. https://doi.org/10.1016/j.bi ortech.2007.01.047

Paludo, C.R., E.A. da Silva-junior, R.A. Santos, M.T. Pupo, F.S. Emery, and N.A.J.C. Furtado. 2013. Microbial transformation of $\beta$-lapachone to its glycosides by Cunninghamella elegans ATCC 10028b. Phytochem. Lett. 6(4):657-661. https://doi.org/10.1016/j.phytol.201 3.08.014

Pan, G. and H.M. Dutta. 1998. The inhibition of brain acetylcholinesterase activity of juvenile largemouth bass Micropterus salmoidesby sublethal concentrations of diazinon. Environ. Res.79(2):133-137. https://doi.org/1 0.1006/enrs. 1998.3868

Pereira, W.E., C.E. Rostad, T.J. Leiker, D.M. Updegraff, and J.L. Bennett. 1988. Microbial hydroxylation of quinoline in contaminated groundwater: evidence for incorporation of the oxygen atom of water. Appl. Environ. Microbiol. 54(3):827-829.

Pimentel, D. and L. Levitan. 1986. Pesticides amount applied and amount reaching pests. BioScience 36(2):86-91. https://doi.org/10.2307/1310108

Poeggeler, B., P. Durand, A. Polidori, M.A. Pappolla, I. Vega-Naredo, A. Coto-Montes, J. Böker, R. Hardeland, and B. Pucci. 2005. Mitochondrial medicine: Neuroprotection and life extension by the new amphiphilic nitrone LBPNAH acting as a highly potent antioxidant agent. J. Neurochem. 95(4):96-973. https://doi.org/10.1111/j.1 471-4159.2005.03425.x

Poeggeler, B. and R. Hardeland. 2001. Observations on melatonin oxidation and metabolite release by unicellular organisms and small aquatic metazoans. In: R. Hardeland (Ed.), Actions and redox properties of melatonin and other aromatic amino acid metabolites (pp. 66-69). Göttingen, Germany: Cuvillier.

Pothuluri, J.V., F.E. Evans, T.M. Heinze, P.P. Fu, and C.E. Cerniglia. 1996. Fungal metabolism of 2-nitrofluorene. J. Toxicol. Environ. Health 47(6):587-599. https://doi.or g/10.1080/009841096161555

Ramakrishnan, B., M. Megharaj, K. Venkateswarlu, R. Naidu, and N. Sethunathan. 2010. The impacts of environmental pollutants on microalgae and cyanobacteria. Crit. Rev. Environ. Sci. Technol. 40(8):699-821. https://doi.org/10.

\section{$1080 / 10643380802471068$}

Reineke, A.K., T. Göen, A. Preiss, and J. Hollender. 2007. Quinoline and derivatives at a tar oil contaminated site: hydroxylated products as indicator for natural attenuation? Environ. Sci.Technol. 41(15):5314-5322. https://doi.org/ $10.1021 / \mathrm{es} 070405 \mathrm{k}$

Riediger, S., A. Behrends, B. Croll, I. Vega-Naredo, N. Hänig, B. Poeggeler, J. Böker, S. Grube, J. Gipp, A. Coto-Montes, C. Haldar, and R. Hardeland. 2007. Toxicity of the quinalphos metabolite 2-hydroxyquinoxaline: Growth inhibition, induction of oxidative stress and genotoxicity in test organisms. Environ. Toxicol. 22(1):33-43. https://doi.org/10.1002/tox.20231

Sadiqul, I.M., S.M. Kabir, Z. Ferdous, K.M. Mansura, and R.M. Khalilur. 2017. Chronic exposure to quinalphos shows biochemical changes and genotoxicity in erythrocytes of silver barb, Barbonymus gonionotus. Interdiscip. Toxicol. 10(3):99-106. https://doi.org/10.1515/intox-20 17-0016

Sarkar, R., K.P. Mohanakumar, and M. Chowdhury. 2000. Effects of an organophosphate pesticide, quinalphos, on the hypothalamo-pituitary-gonadal axis in adult male rat. J. Reprod. Fertil. 118(1):29-38.

Schwarz, G., E. Senghas, A. Erben, B. Schäfer, F. Lingens, and H. Höke. 1988. Microbial metabolism of quinoline and related compounds: I. Isolation and characterization of quinoline-degrading bacteria. Syst. Appl. Microbiol. 10(2):185-190. https://doi.org/10.1016/S0723-2020(88) 80035-3

Silman, I. and J.L. Sussman. 2005. Acetylcholinesterase: classical and non-classical functions and harmacology. Curr. Opin. Pharmacol. 5(3):293-302. https://doi.org/10. 1016/j.coph.2005.01.014

Sochová, I., J. Hofman, and I. Holoubek. 2011. Effects of seven organic pollutants on soil nematode Caenorhabditis elegans. Environ. Int. 33(6):798-804. https://doi.org/10. 1016/j.envint.2007.03.001

Subba Reddy, G.V. 2013. Bacterial degradation of an organophosphorus insecticide - Quinalphos. Doctoral dissertation, Sri Krishnadevaraya University, Anantapuramu, A.P. India.

Subba Reddy, G.V., M.M. Rafi, S. Rubesh Kumar, N. Khayalethu, D.M. Rao, B. Manjunatha, G.H. Philip, and B.R. Reddy. 2016. Optimization study of 2-hydrox- 
yquinoxaline (2-HQ) biodegradation by Ochrobactrum sp. HQ1. 3 Biotech. 6, 51. https://doi.org/10.1007/s1320 5-015-0358-6

Subba Reddy, G.V., B.R. Reddy, and M.G. Tlou. 2014. Biodegradation of 2-hydroxyquinoxaline (2-HQ) by Bacillus sp. J. Hazard. Mater. 278:100-107. https://doi.o rg/10.1016/j.jhazmat.2014.05.080

Sun, Q.H., Y.H. Bai, C. Zhao, Y.N. Xiao, D.H. Wen, and X.Y. Tang. 2009. Aerobic biodegradation characteristics and metabolic products of quinoline by a Pseudomonas strain. Bioresour. Technol. 100(21):5030-5036. https://d oi.org/10.1016/j.biortech.2009.05.044

Talwar, M.P., S.I. Mulla, and H.Z. Ninnekar. 2014. Biodegradation of organophosphorus pesticide quinalphos by Ochrobactrum strain HZM. J. Appl. Microbiol. 117(5):1283-1292. https://doi.org/10.1111/jam.12627

Teixeira, H., P. Proença, M. Alvarenga, M. Oloveira, E.P. Marques, and D.N. Vieira. 2004. Pesticide intoxications in the center of Portugal: Three years analysis. Forensic Sci. Int. 143(2-3):199-204. https://doi.org/10.1016/j.fors ciint.2004.02.037

Tuo, B.H., J.B. Yan, B.A. Fan, Z.H. Yang, and J.Z. Liu. 2012. Biodegradation characteristics and bioaugmentation potential of a novel quinoline-degrading strain of Bacillussp. isolated from petroleum-contaminated soil. Bioresour. Technol. 107:55-60. https://doi.org/10.1016/ j.biortech.2011.12.114

Vairamuthu, S. and M. Thanikachalam. 2003. The effect of quinalphos on blood and brain esterase activity in chicken. Indian Vet. J. 80(11):1160-1163.

Vasilić, Z., V. Drevenkar, V. Rumenjak, B. Štengal, and
Z. Fröbe. 1992. Urinary excretion of diethylphosphorus metabolites in persons poisoned by quinalphos or chlorpyrifos. Arch. Environ. Contam. Toxicol. 22(4): 351-357. https://doi.org/10.1007/BF00212552

Venkateswarlu, K. 1993. Pesticide interactions with cyanobacteria in soil and pure culture. In: J.M. Bollag and G. Stotzky (Eds.), Soil Biochemistry, Vol. 8(pp. 137-179). New York, NY: Marcel Dekker, Inc.

Vig, K., D.K. Singh, and P.K. Sharma. 2006. Endosulfan and quinalphos residues and toxicity to soil microarthropods after repeated applications in a field investigation. J. Environ. Sci. Health B 41(5):681-692. https://doi.org/10.1080/03601230600701841

Wang, C., M. Zhang, F. Cheng, and Q. Geng. 2014. Biodegradation characterization and immobilized strains potential for quinoline degradation by Brevundimonassp. K4 isolated from activated sludge of coking wastewater. Biosci. Biotechnol. Biochem. 79(1):164-170. https://doi. org/10.1080/09168451.2014.952615

Wang, P.Y., H. Chen, Y. Wang, Y.K. Lyu. 2020. Quinoline biodegradation characteristics of a new quinoline-degrading strain, Pseudomonas citronellolis PY1. J. Chem. Technol. Biotechnol. 95(8):2171-2179. https://doi.org/10.1002/jct b.6403

World Health Organization. 2004. WHO recommended classification of pesticides by hazard and guidelines to classification.

Zhu, S.N., D.Q. Liu, L. Fan, and J.R. Ni. 2008. Degradation of quinoline by Rhodococcus sp. QL2 isolated from activated sludge. J. Hazard. Mater. 160(2-3):289-294. https://doi.org/10.1016/j.jhazmat.2008.02.112 